\title{
Assessment of anthropogenic impacts on carbon sequestration potential of a moist semi- deciduous forest in Eastern Ghana
}

\begin{abstract}
Carbon sequestration is associated with plant biomass and soils. The amount of carbon sequestration in the Atewa Range Forest Reserve (ARFR) is affected by varied anthropogenic activities like logging, mining and farming. This study estimate the above and below ground carbon stock and assess human-induced stress impacts on the Highly Stressed Vegetation (HSV), Moderately Stressed Vegetation (MSV), and Non-Stressed Vegetation (NSV) in the ARFR. The above ground biomass of trees was determined using the allometric model of (Henry, et al., 2010) whereas plants root biomass was calculated using Cairns et al. (1997). Soil organic carbon was determined using the Walkley-Black method. We observed that carbon stock was higher in the above-ground than the below-ground component. The MSV, recorded the highest stock of carbon followed by the NSV and the HSV whilst sequestrated carbon stocks was generally high and varied across the three stress levels. Within the forest, the intensity of anthropogenic activities has negatively impacted the amounts of carbon sequestrated at various levels.
\end{abstract}

Key words: Above ground biomass; Anthropogenic; Below ground biomass; Carbon sequestration; Forest 


\section{Introduction}

Carbon sequestration is defined as the process of capturing and the long term storage of the atmospheric carbon dioxide $\left(\mathrm{CO}_{2}\right)$ (Sedjo and Sohngen, 2012). According to Lal (2004), carbon sequestration may refer to the transfer of atmospheric $\mathrm{CO}_{2}$ into long-lived pools and securely storing it for future remittance. The sequestration of carbon may refer also to the artificial or natural process through which carbon dioxide is either taken or removed from the atmosphere and stored in a liquid or solid form (Hongqun et al., 2008). Numerous forests exist mostly across the equator and other regions of the globe including South and Central America, Africa, Southeast Asia and some Pacific Islands etc. About 422 billion metric tons of above ground forests are known to exist with a quarter of the proportion found in South America (Cunnigham and Cunningham, 2006). With about 3.9 billion ha of land area made up of woodlands, thorn scrub, Savanna as well as closed canopy forests, the largest forest areas could be found in Europe including Russia's vast boreal forest. The largest tropical forests however are found in South America's Amazon basin. Although Africa has a significant percentage of the global forest cover, the highest annual rates of forest disturbance through anthropogenic means occur in there.

The differences observed in carbon storage among tropical forests are an indication of the variation in a number of factors, such as tree community composition, successional stage, stressors history, climate, and soil fertility (Wei et al., 2013). Secondary forests are of specific importance, assuming that the proportion of tropical forests that are secondary is predictable to continue to rise due to increasing anthropogenic pressure and the movement of populations towards urban centres (Thomlinson et al., 1996; Wright, 2005). This however implies that carbon stocks and uptake in secondary forests may be increasingly important for global tropical forest carbon budgets.

Mankind has the potential to greatly influence atmospheric carbon dioxide concentrations through the effects of land use change and forest management activities on the terrestrial biomass carbon pool. Facing the increasing carbon dioxide concentration in the atmosphere and its germaneness for the earth's climate system, new and precise information is required on the carbon exchange of forest ecosystems at all latitudes (Grünwald \& Bernhofer, 2007). Gorte (2009) has indicated that upland evergreen forests play essential roles in carbon sequestration by seizing much higher quantity than any other biome. Basically, carbon sequestration refers to the transfer of atmospheric carbon dioxide into long-lived pools and storing it securely so it is not directly re-emitted (Kambale \& Tripathi, 2010).

The estimation of the amount of forest biomass is very essential for monitoring and estimating the amount of carbon lost or emitted as a result of deforestation and land use change. This is because it gives the researcher an idea of the forest's potential to sequester and store carbon in the forest ecosystem. Terrestrial carbon sequestration is a natural process and a possible strategy for reducing the rate of enrichment of atmospheric carbon dioxide $\left(\mathrm{CO}_{2}\right)$. The terrestrial carbon pool in tropical forest ecosystems comprises $120 \mathrm{Mg} / \mathrm{ha}$ (tonnes) in vegetation and $123 \mathrm{Mg} / \mathrm{ha}$ in soil to a depth of 1 metre (Lai, 2004). Five carbon pools of the terrestrial ecosystem involving biomass have been identified by the Intergovernmental Panel on Climate Change (IPCC), namely the below-ground biomass, above-ground biomass, litter, soil organic and woody debris 
matter. Among the five pools mentioned, the above-ground biomass comprises the main portion of the carbon pool and is principally the main one which is directly affected by forest degradation and deforestation as a result of logging, mining and farming. Roger (1993) estimated that about $86 \%$ of the terrestrial above-ground carbon and $73 \%$ of the earth's soil carbon are deposited in the forests. However, changes associated with land use system have a direct impact on the above carbon pool. Thus, forest clearing can lead to soil degradation, erosion, and the leaching of soil nutrients, and may reduce the ability of the ecosystem to act as a carbon sink.

Below-ground biomass accumulation is linked to the dynamics of above-ground biomass. Eggleston, Buendia, Miwa, Ngara and Tanabe (2006), have indicated that the below-ground biomass is made up of all live roots and this plays an essential role in the carbon cycle by moving and storing carbon in the soil. By definition, below-ground biomass is the entire biomass of all live roots, often excluding fine roots of less than $2 \mathrm{~mm}$ diameter since they cannot be empirically distinguished from soil organic matters (Ravindranath \& Ostwald, 2008). Belowground biomass is an essential carbon pool for most land-use systems and vegetation types as it accounts for about $20-24 \%$ of the total biomass whilst the highest proportion of root biomass happens in the top $30 \mathrm{~cm}$ of the soil surface (De Deyn, Cornelissen, \& Bardgett, 2008). Thus, the concentration of carbon in soil has an effect on the above and below ground forest production. According to Schimel (1995), soils in the forest ecosystem accumulates the largest quantity of soil organic carbon, more than $1500 \mathrm{pg}$ carbon or approximately two times as much as carbon in the air, and more than two and a half times carbon in plant structure. This study is much interested in the terrestrial sequestration, since terrestrial sequestration is on how plants capture $\mathrm{CO}_{2}$ from the atmosphere and then storing it as carbon in the stems and roots of the plants as well as in the soil. Other information that would be garnered includes soil water content, temperature, and the above and below ground biomass. The data collection process would incorporate an in-depth experimental measurement in an effort to ascertain the status of carbon sequestration, soil and water in an upland evergreen tropical forest of ARFR.

Comparing Ghana's forest carbon sequestration to that of the entire continent, the forest in Ghana is observed to contain a biomass of about 1,132 megatonnes of carbon $\left(1 \mathrm{MtC}=10^{6}\right.$ tonnes) against 60 gigatonnes of carbon for Africa forest $\left(1 \mathrm{GtC}=10^{9}\right.$ tonnes) (FAO, 2005). Carbon mapping statistics of Ghana further indicates that, the country's terrestrial carbon stocks may be projected to $2.04 \mathrm{Gt}$ in totality. This according to the Forestry Commission is made up of $1.7 \mathrm{Gt}$ carbon in above- and below-ground biomass and approximately $0.34 \mathrm{Gt}$ in soils to $1 \mathrm{~m}$ depth. That notwithstanding, Ghana has an uneven distribution of both biomass and soil carbon with high biomass carbon density cover of $6 \%$ in approximately $2 \%$ of the nation's total land area. 


\section{Materials and Methods}

\subsection{Study area}

\subsection{Data collection}

\subsubsection{Measurements of Tree Biomass and Carbon Stocks}

Above ground biomass of trees was determined using the allometric model of (Henry, et al., 2010). The allometry estimates tree biomass as $Y=0.30 \times \mathrm{dbh}^{2.31}$, where $\mathrm{Y}$ is tree biomass and $\mathrm{dbh}$ the diameter at breast height. The model which was specifically developed for tropical African forest has been used in similar studies by Asitoakor (2011) and Asase et al. (2014). The $\mathrm{dbh}$ measurements which were taken during the enumeration of plant diversity in the $25 \mathrm{x} 25 \mathrm{~m}$ sub-plots were used in the estimation of the biomass. Plant root biomass was calculated indirectly from the above ground biomass estimated according to methods of Cairns et al. (1997) these researcher estimated root biomass to be approximately a quarter of the above-ground biomass. Following the estimated biomass obtained, tree carbon was calculated as half the Albrecht \& Kandji (2003) and Glenday (2006) postulate that the amount of tree carbon is half the biomass calculated from the method of Cairns et al. (1997).

\subsubsection{Determination of soil characteristics}

To determine the physical, chemical and biological properties of soils in the study area, soil samples were taken from the four corners and center of the sub-plots at depths of $0-15$ and $15-$ $30 \mathrm{~cm}$ using a soil auger. The soil samples were air-dried to obtain constant weight. Various soil parameters including soil carbon stocks, soil respiration, soil particle size, $\mathrm{pH}$ etc., were determined by the using various standard methods.

\subsubsection{Determination of Soil Carbon Stock}

To determine soil organic carbon, soil samples were collected from two randomly selected spots in each of the $25 \times 25 \mathrm{~m}$ vegetation types based on stress intensity. Soil samples were collected at two different depths, namely $0-15$ and $15-30 \mathrm{~cm}$, since soil carbon stocks vary with depth (Williams et al., 2008). Previous works have sampled soil carbon stocks in the tropics at similar depths (Kirby \& Potvin, 2007; Williams et al., 2008). Percentage soil organic carbon was determined using the Walkley-Black method (Walkley \&Black 1934) as modified by Anderson and Ingram (1989) and corrected for the un-oxidized organic carbon as described by Nelson and Sommers (1996). 


\section{Results}

\subsection{Impacts of Stress levels on Carbon Stocks}

A total of 2,648.72 $\mathrm{Mg} \mathrm{C} \mathrm{ha}^{-1}$ was estimated as the above ground and below ground biomass of the woody plants during the study with a mean of $176.58 \pm 64.51 \mathrm{Mg} \mathrm{C} \mathrm{ha}^{-1}$. Of the total estimated carbon, $2,136.06 \mathrm{Mg} \mathrm{C}^{-1}$ constituted the above-ground carbon with $512.5 \mathrm{Mg} \mathrm{C}^{-1}$ accounting for the below-ground carbon recorded. A mean of $142.40 \pm 32.91 \mathrm{Mg} \mathrm{C} \mathrm{ha}^{-1}$ was obtained as the above-ground carbon whereas $34.18 \pm 7.90 \mathrm{Mg} \mathrm{C} \mathrm{ha}^{-1}$ was the average belowground carbon obtained. Although there was no significant variation $\left(\mathrm{F}_{2,12}=1.0 \mathrm{p}=0.396\right)$ in the total amount of carbon sequestrated at the various stress levels, the MSV contributed the highest amount of carbon followed by the NSV and HSV.

Table 1: Woody plant density (WPD), biomass (Mg) and carbon stocks (Mg $\mathrm{C} \mathrm{ha}^{-1} \pm$ s.e.) per plot in the three stressed levels in the study area

\begin{tabular}{lllll}
\hline Parameter & HSV & MSV & NSV & P-value \\
\hline WPD & $105.20 \pm 28.78$ & $120.60 \pm 20.08$ & $127.80 \pm 24.47$ & 0.367 \\
Biomass & $289.44 \pm 57.66$ & $401.96 \pm 72.35$ & $368.08 \pm 62.66$ & 0.396 \\
AGC & $116.71 \pm 46.50$ & $162.08 \pm 58.35$ & $148.42 \pm 50.53$ & 0.396 \\
BGC & $28.01 \pm 11.16$ & $38.90 \pm 14.00$ & $35.62 \pm 12.13$ & 0.396 \\
\hline
\end{tabular}

Thus, in the above ground biomass category, the HSV accounted for $27.32 \%$ of the total carbon measured as against $37.94 \%$ from the MSV and 34.74\% from the NSV. The same percentages were recorded for the various stress levels in terms of the below-ground carbon measured.

\subsection{Carbon Stocks based on Ecological Guilds in the Study Area}

Tree-stored carbon stock per plot ranged from 144.72 \pm 57 for HSV through $200.98 \pm 72.35$ for MSV to184.05 $\pm 62.66 \mathrm{Mg} \mathrm{C}$ ha ${ }^{-1}$ for NSV. Although there was no significant difference $(\mathrm{p}=$ 0.347 ) in the total mean tree-stored carbon stocks contributed by the different ecological guilds, the highest amount of tree-stored carbon $\left(33.53 \pm 3.6 \mathrm{Mg} \mathrm{C} \mathrm{ha}^{-1}\right)$ was recorded for the Shadebearer followed by NPLD $\left(23.59 \pm 6.31 \mathrm{Mg} \mathrm{C} \mathrm{ha}^{-1}\right)$ and Pioneer $\left(21.01 \pm 4.32 \mathrm{Mg} \mathrm{C}^{-1}\right)$ species. The least amount of tree-stored carbon was however contributed by Savanna/ Non forest $\left(1.56 \pm 0.62 \mathrm{Mg} \mathrm{C} \mathrm{ha}^{-1}\right)$ and Swamp $\left(0.37 \pm 0.31 \mathrm{Mg} \mathrm{C}^{-1}\right)$. Table 10, displays the measured carbon stocks based on the ecological guilds in the three land-use types. The largest contribution of tree-stored carbon stocks by pioneer species was recorded in the HSV which formed about $24.75 \%$ of the total mean tree-stored carbon. In the MSV and the NSV, the largest contribution to above ground carbon stocks was recorded for the Shade-Bearers species with $42.15 \%$ and $40.96 \%$ contributions respectively. 
Table 2: Carbon stocks ( $\left.\mathrm{Mg} \mathrm{C} \mathrm{ha}{ }^{-1}\right)$ according to ecological guilds and stress level

\begin{tabular}{llllll}
\hline \multirow{2}{*}{ Carbon Pool } & & \multicolumn{3}{l}{ Stress Levels } & \\
\cline { 2 - 5 } & Ecological Guild & HSV & MSV & NSV & Total \\
\hline Above-Ground Carbon & NPLD & 14.04 & 23.59 & 23.51 & 61.14 \\
& Pioneer & 14.6 & 21.01 & 14.75 & 50.36 \\
& Savanna/Non forest & 21.34 & 0.23 & 1.56 & 23.13 \\
& Shade-Bearer & 6.84 & 33.53 & 30.74 & 71.11 \\
& Swamp & 0.37 & 0.31 & 0.32 & 1 \\
& Unknown & 1.83 & 0.88 & 4.18 & 6.89 \\
Below-Ground Carbon & NPLD & 3.37 & 5.66 & 5.64 & 14.67 \\
& Pioneer & 3.5 & 5.04 & 3.54 & 12.08 \\
& Savanna/Non forest & 5.12 & 0.06 & 0.38 & 5.56 \\
& Shade-Bearer & 1.64 & 8.05 & 7.38 & 17.07 \\
& Swamp & 0.09 & 0.08 & 0.08 & 0.25 \\
& Unknown & 0.44 & 0.21 & 1 & 1.65 \\
& NPLD & 17.41 & 29.25 & 29.15 & 75.81 \\
& Pioneer & 18.1 & 26.05 & 18.29 & 62.44 \\
& Savanna/Non forest & 26.46 & 0.29 & 1.94 & 28.69 \\
& Shade-Bearer & 8.48 & 41.58 & 38.12 & 88.18 \\
& Swamp & 0.45 & 0.39 & 0.39 & 1.23 \\
& Unknown & 2.26 & 1.09 & 5.18 & 3.35 \\
\hline
\end{tabular}

Specifically from the HSV, the Savanna/Non forest species were identified as the major contributor to the total carbon sequestrated (Figure 1). 


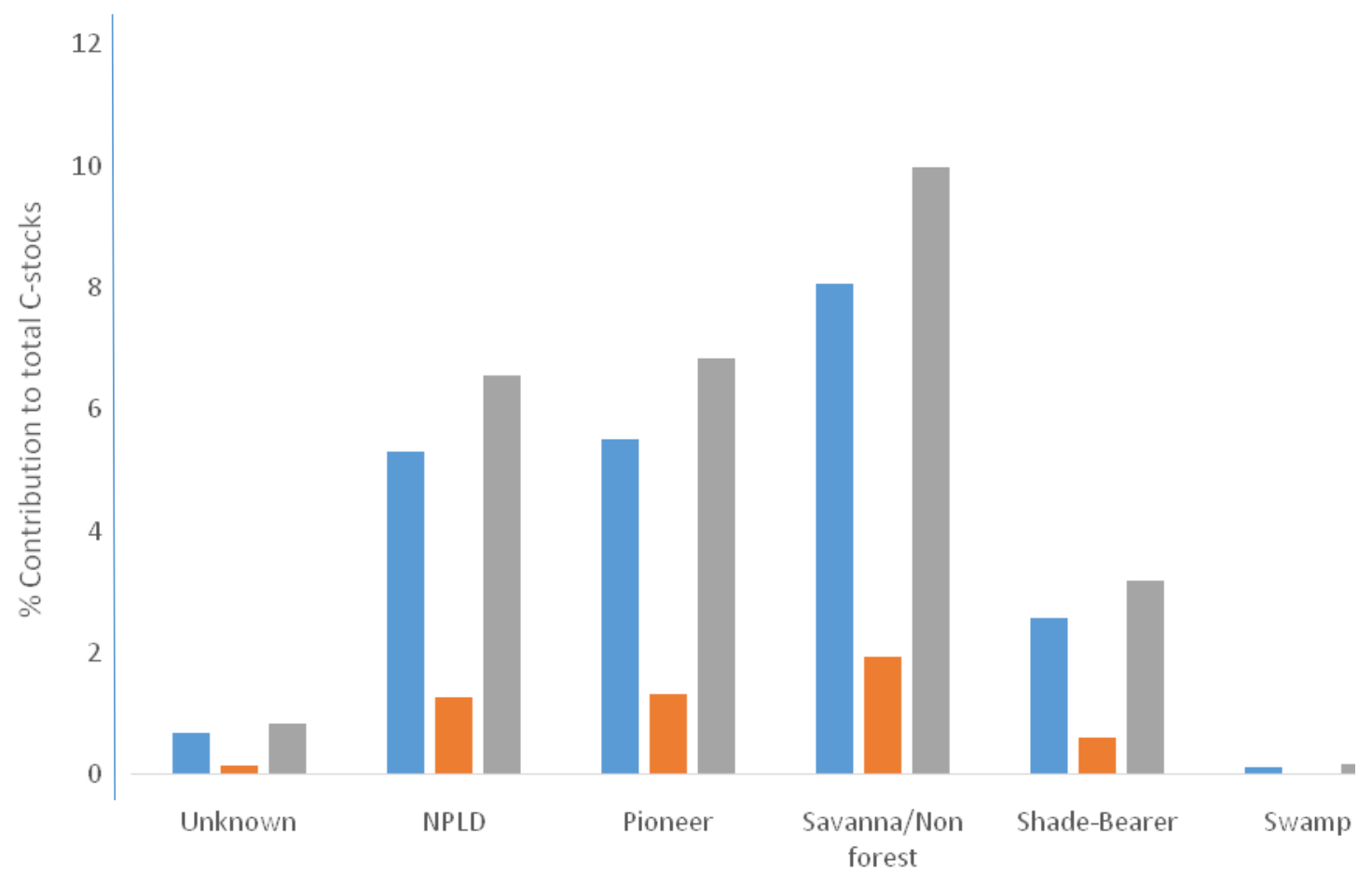

Ecological guilds

above-Ground Carbon $\quad$ Below-Ground Carbon $\quad$ Total Above+Below Carbon

Figure 1: Percentage contribution of ecological guild to total carbon in the HSV

However, in the MSV and NSV areas, the Shade-bearers, the Non-Pioneer Light Demanders and the Pioneer species sequestrated the most carbon (Figures 1 and 2). 


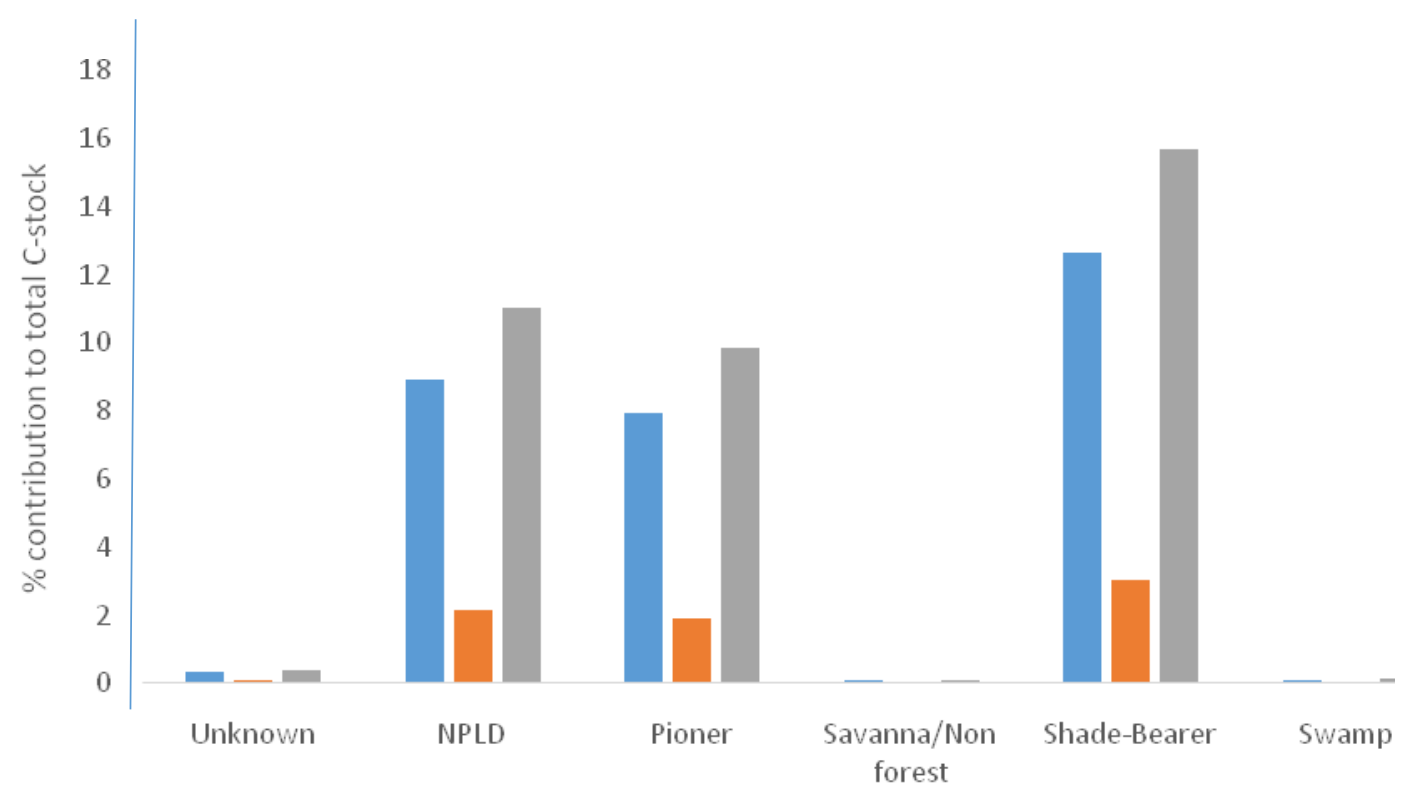

Ecological guilds

above-Ground Carbon $\quad$ Below-Ground Carbon $\quad$ Total Above+Below Carbon

Figure 2: Percentage contribution of ecological guild to total carbon in the MSV

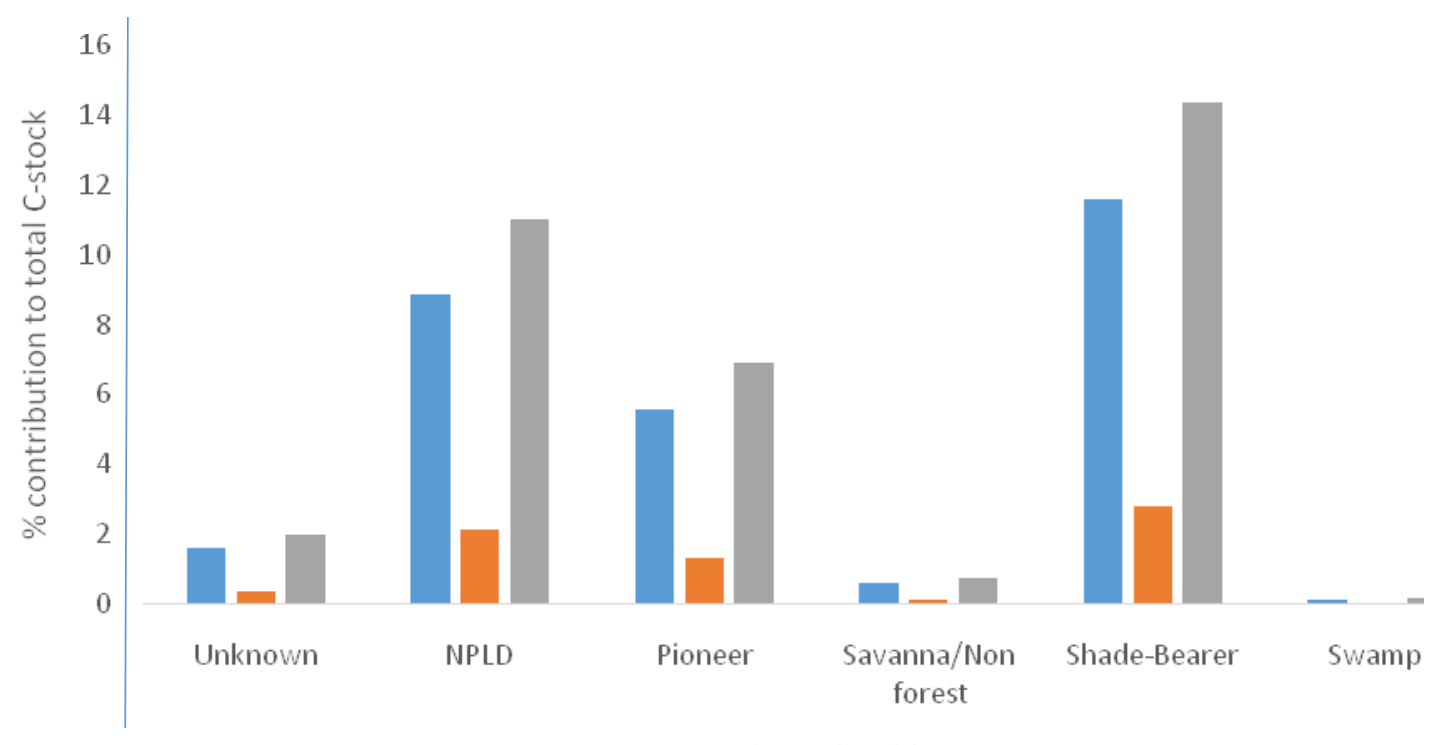

Ecological guilds

above-Ground Carbon $\quad$ Below-Ground Carbon $\quad$ Total Above+Relow Carbon

Figure 3: Percentage contributions of ecological guild to total carbon in the NSV 
Table 3 further gives the correlation analysis of the various vegetation characteristics and the soil characteristics. Apart from tree dominance which showed significant correlation with sequestrated carbon, there was no significant correlation between the vegetation characteristics and the soil parameters assessed (Table 3)

Table 3: Correlation analyses between carbon stocks, tree diversity and soil characteristics

\begin{tabular}{|c|c|c|}
\hline Carbon stocks pools & Variables & $\begin{array}{l}\text { Correlation } \\
\text { coefficients, p-value }\end{array}$ \\
\hline Total carbon stocks & $\begin{array}{l}\text { Species richness of tree } \\
\text { Density of trees } \\
\text { Dominance of trees } \\
\text { Shannon-wiener index for trees } \\
\text { Simpson index for trees } \\
\text { Soil potassium content } \\
\text { Soil phosphorus content } \\
\text { soil nitrogen content } \\
\text { soil carbon } \\
\text { Soil bulk density } \\
\text { Soil pH }\end{array}$ & $\begin{array}{l}-0.023, p=0.93 \\
-0.026, p=0.93 \\
0.94, p=4.7 e-06 \\
0.22, p=0.32 \\
0.25, p=0.43 \\
0.38, p=0.43 \\
0.31, p=0.35 \\
0.59, p=0.053 \\
0.44, p=0.18 \\
-0.57, p=0.071 \\
0.55, p=0.059\end{array}$ \\
\hline Total above-ground & Species richness of tree & $-0.033, p=0.96$ \\
\hline & $\begin{array}{l}\text { Density of trees } \\
\text { Dominance of trees } \\
\text { Shannon-wiener index for trees } \\
\text { Simpson index for trees }\end{array}$ & $\begin{array}{l}-0.041, p=0.87 \\
0.91, p=3.9 \mathrm{e}-07 \\
0.28, p=0.48 \\
0.22, p=0.43\end{array}$ \\
\hline $\begin{array}{l}\text { Total above-ground } \\
\text { carbon stocks }\end{array}$ & $\begin{array}{l}\text { Soil potassium content } \\
\text { Soil phosphorus content } \\
\% \text { soil nitrogen content } \\
\% \text { soil carbon } \\
\text { Soil bulk density } \\
\text { Soil pH }\end{array}$ & $\begin{array}{l}0.33, p=0.25 \\
0.32, p=0.37 \\
0.51, p=0.065 \\
0.43, p=0.21 \\
-0.55, p=0.064 \\
0.56, p=0.055\end{array}$ \\
\hline $\begin{array}{l}\text { Total soil organic carbon } \\
\text { (SOC) }\end{array}$ & $\begin{array}{l}\text { Species richness of tree } \\
\text { Density of trees } \\
\text { Dominance of trees } \\
\text { Shannon-wiener index for trees } \\
\text { Simpson index for trees } \\
\text { Simpson index for trees } \\
\text { Soil potassium content } \\
\text { Soil bulk density } \\
\text { Soil pH }\end{array}$ & $\begin{array}{l}0.25, p=0.47 \\
0.34, p=0.32 \\
-0.23, p=0.56 \\
0.5, p=0.40 \\
0.36, p=0.33 \\
0.32, p=0.38 \\
0.45, p=0.27 \\
0.15, p=0.76 \\
-0.14, p=0.63\end{array}$ \\
\hline
\end{tabular}




\section{Discussion}

\subsection{Anthropogenic Influences on Carbon Sequestration and Stock in the Vegetation}

Tropical deforestation through land-use changes accounts for approximately $25 \%$ of carbon emissions from anthropogenic sources (IPPC, 2001; Thomas, et al., 2004). In tropical forest environments, carbon sequestration is mostly associated with plant biomass and soils (BlancoCanqui \& Lal, 2004; Kaiser, Eusterhues, Rumpel, Guggenberger, \& Kogel-Knabner, 2002; Lal, 2003; Lamlom \& Savidge, 2003) with pieces of evidence linking higher carbon stocks to higher plant species diversity and density (Catovsky, Kobe, \& Bazzaz, 2002; Kirby \& Potvin, 2007). Nonetheless, the amount of carbon sequestration in a forest may be affected by varied anthropogenic activities like logging, mining and farming. The findings of the study indicated that in the ARFR, the relatively high amount of sequestrated carbon was observed at the MSV followed by the NSV and the HSV. This finding is similar to observations made by Asase et al. (2012) in the Bia Conservation Area in the Western Region of Ghana and Katovai et al. (2015) for the tropical rainforest in Papua New Guinea. The results for both the above- and belowground biomass components of the tree species show that the MSV contributed most to the sequestrated carbon, followed by the NSV and the HSV. The finding of the current study is consistent with the findings of Asase et al (2012) and Katovai et al (2015) who indicated that lower carbon is an indication of the negative impact of anthropogenic activities. It contradicts the finding of Berenguer et al. (2014) who reported that regardless of disturbances, the patterns of carbon stocks were similar for both the primary and secondary forests in the Amazon.

The slightly lower carbon stock in the Atewa forest compared to the cited studies might be due to the different land-uses and the magnitude of disturbances observed. The ARFR has in recent times witnessed massive encroachments from the activities of illegal gold mining, logging, farming and settlement. The Bia Conservation Area has attracted national and international interest towards the protection of biological species (IUCN, 2010). As suggested by Smith and Stitt (2007) increasingly anthropogenic activities are becoming common in most tropical forests as these forest resources are largely connected with the lives of the ever increasing population. Nevertheless, over dependence on the forest ecosystem for socio-economic and cultural relief is putting too much stress on it. Thus, growing human population is contributing to agricultural expansion and intensification, and logging. These are major causes of deforestation, degradation, biodiversity loss and significant carbon emission during the past decades in forest ecosystem (Van Gemerden, et al., 2003; Norris, et al., 2010).

\subsection{Contributions of Ecological Guilds to Tree-Stored Carbon Stocks in the Study Area}

The carbon stock per plot is made-up of the contributions from Shade-Bearers, Pioneer NonPioneer Light Demanders, Savanna/Non-forest and swamp. The shade-bearers recorded the highest carbon stock, followed by the Non Pioneer Light Demanders and the other ecological guilds differ from the observation of Yeboah (2011) for the Oda-kotoamso and the Bobiri forest reserve of Ghana. Yeboah (2011) found that tree carbon content did not differ for the guilds classification, that is the pioneer, non-pioneer light demanders, and shade bearers. The large proportions of Savanna or Non-forest species recorded in the HSV can be attributed to the 
anthropogenic activities in that area which has led to the transformation of the vegetation from the expected rainforest to the savanna vegetation, as has been observed above. As expected the largest contribution of tree stored carbon stocks by Pioneer species was recorded in the HSV while the MSV and the NSV recorded the largest contribution of tree stored carbon stocks from the Shade-Bearers.

\section{Conclusion}




\section{REFERENCES}

Allotey, J. A. (2007). Status of biodiversity and impact assessment in Ghana. Accra: Environmental Protection Agency Ghana.

Anderson, J. M., \& Ingram, J. S. (1989). Tropical Soil Biology and Fertility: A Handbook of Methods. Wallingford, UK: CAB International.

Asase, A., Asiatokor, B. K., \& Ofori-Frimpong, K. (2014). Effects of selective logging on tree diversity and some soil characteristics. Journal of Forestry Research, 25(1), 171-176.

Asase, A., Asitoakor, B. K., \& Ekpe, P. K. (2012). Linkages between tree diversity and carbon stocks in unlogged and logged West African tropical forests. International Journal of Biodiversity Science, Ecosystem Services \& Management, 8(3), 217-230.

Berenguer, E., Ferreira, J., Alan, G. T., Araga, L. E., De Camargo8, P. B., Cerri, C. E., Vieira, I. C. (2014). A large-scale field assessment of carbon stocks in human-modified tropical forests. Global Change Biology, 20, 37133726.

Blanco-Canqui, H., \& Lal, R. (2004). Mechanisms of Carbon Sequestration in Soil Aggregates. Critical Reviews in Plant Sciences, 23(6), 481-504.

Cairns, M. A., Brown, S., Helmer, E. H., \& Baumgardner, G. A. (1997). Root biomass allocation in the world's upland forests. Oecologia, 111, 1-11.

Catovsky, S., Kobe, R. K., \& Bazzaz, F. A. (2002). Nitrogen-induced changes in seedling regeneration and dynamics of mixed conifer-broad-leaved forests. Ecol Appl., 12, 16111625.

Cunningham, W. P., \& Cunningham, M. A. (2006). Principles of Environmental Science. India: Pearson Education.

De Deyn, G. B., Cornelissen, J. H., \& Bardgett, R. D. (2008). Plant functional traits and soil carbon sequestration in contrasting biomes. Ecology Letters, 11, 
516-531.

Eggleston, H. S., Buendia, L., Miwa, K., Ngara, T., \& Tanabe, K. (2006). IPCC

Guidelines for National Greenhouse Gas Inventories. Hayama, Japan: Institute of Global Environmental Strategies (IGES),

FAO. (2005, 09 11). Global forest resources assessment 2005. Retrieved from http://www.fao.org/forestry/fra/fra2005/en/.:

Gorte, R. W. (2009). Carbon Sequestration in Forests. Washington: CSR.

Grünwald, T., \& Bernhofer, C. (2007). A decade of carbon, water and energy flux measurements of an old spruce forest at the Anchor Station Tharandt. Tellus B, 59(2), 387-396.

Henry, M. (2010). Carbon stocks and dynamics in Sub Saharan Africa. Tuscia: University of Tuscia.

Hongqun, D. (2008). Design of the Contact Metallizations for Gold-Tin Eutectic Solder-A Thermodynamic-Kinetic Analysis. Aalto: Aalto University publication series.

IPPC. (2001). Integrated Pollution Prevention and Control (IPPC): reference document on best available techniques in the pulp and paper industry. . Brussels (Belgium): European Commission.

IUCN. (2007). The IUCN Species Survival Commission 2007 IUCN Red List of threatened species. IUCN, Gland .

Kambale, J. B., \& Tripathi, V. K. (2010). Biotic and Abiotic Processes as a Carbon sequestration Strategy. Journal of Environmental Research and Development, 5(1).

Katovai, E., Edwards, W., \& Laurance, W. F. (2015). Dynamics of logging in Solomon Islands: The need for restoration and conservation alternatives.

Tropical Conservation Science, 8(3), 718-731.

Smith, A. M., \& Stitt, M. (2007). Coordination of carbon supply and plant growth. Plant Cell Environ., 30, 1126-1149.

Van Gemerden, B. S., Shu, G. N., \& Olff, H. (2003). Recovery of conservation values in Central African rain forest after logging and shifting cultivation. 
Biodiversity \& Conservation, 12(8), 1553-1570.

Yeboah, D. (2011). Variation in carbon content of tropical tree species from Ghana. Michigan: Michigan Technological University. 